\title{
Transient Coexpression of Individual Genes Encoded by the Triple Gene Block of Potato mop-top virus Reveals Requirements for TGBp1 Trafficking
}

\author{
Andrey A. Zamyatnin, Jr., ${ }^{1}$ Andrey G. Solovyev, ${ }^{2}$ Eugene I. Savenkov, ${ }^{1}$ Anna Germundsson, ${ }^{1}$ \\ Maria Sandgren, ${ }^{1}$ Jari P. T. Valkonen, ${ }^{1,3}$ and Sergey Y. Morozov ${ }^{2}$ \\ ${ }^{1}$ Department of Plant Biology and Forest Genetics, Swedish University of Agricultural Sciences (SLU), SE-750 07 Uppsala, \\ Sweden; ${ }^{2}$ A. N. Belozersky Institute of Physico-Chemical Biology, Moscow State University, Moscow 119899, Russia; \\ ${ }^{3}$ Department of Applied Biology, University of Helsinki, Finland
}

Submitted 4 February 2004. Accepted 13 April 2004.

TGBp1, TGBp2, and TGBp3, three plant virus movement proteins encoded by the "triple gene block" (TGB), may act in concert to facilitate cell-to-cell transport of viral RNA genomes. Transient expression of Potato mop-top virus (genus Pomovirus) movement proteins was used as a model to reconstruct interactions between TGB proteins. In bombarded epidermal cells of Nicotiana benthamiana, green fluorescent protein (GFP)-TGBp1 was distributed uniformly. However, in the presence of TGBp2 and TGBp3, GFP-TGBp1 was directed to intermediate bodies at the cell periphery, and to cell wall-embedded punctate bodies. Moreover, GFP-TGBp1 migrated into cells immediately adjacent to the bombarded cell. These data suggest that TGBp2 and TGBp3 mediate transport of GFPTGBp1 to and through plasmodesmata. Mutagenesis of TGBp1 suggested that the NTPase and helicase activities of TGBp1 were not required for its transport to intermediate bodies directed by TGBp2 and TGBp3, but these activities were essential for the protein association with cell wall-embedded punctate bodies and translocation of TGBp1 to neighboring cells. The C-terminal region of TGBp1 was critical for trafficking mediated by TGBp2 and TGBp3. Mutation analysis also suggested an involvement of the TGBp2 C-terminal region in interactions with TGBp1.

Additional keywords: cell-to-cell movement, intracellular trafficking.

Cell-to-cell and systemic spread of Potato mop-top virus (PMTV; type member of the genus Pomovirus) is mediated by three viral proteins encoded by a conserved gene module, the "triple gene block" (TGB) (Koenig et al. 1996; McGeachy and Barker 2000; Savenkov et al. 2003; Scott et al. 1994), also found in three other genera of rod-shaped viruses (Hordeivirus, Pecluvirus, and Benyvirus) and in four genera of filamentous

Corresponding author: A. A. Zamyatnin, Jr.; Telephone: +46 18 673370; Fax: +46 18 673279; E-mail: andrey.zamyatnin@vbsg.sly.se

Current address of M. Sandgren: SBL Vaccin AB, SE-105 21 Stockholm, Sweden.

* The $\boldsymbol{e}$-Xtra logo stands for "electronic extra" and indicates the HTML abstract available on-line contains a supplemental table not included in the print edition. viruses (Potexvirus, Carlavirus, Allexivirus, and Foveavirus) (Morozov and Solovyev 2003). The TGB-encoded proteins are referred to as TGBp1, TGBp2, and TGBp3 according to the 5' to $3^{\prime}$ order of their genes on the viral RNA (Solovyev et al. 1996). They are classified as either hordei-like or potex-like (TGB encoded by PMTV belongs to the hordei-like group), depending on the sizes of TGBp1 and TGBp3. In the hordeilike transport system, only three TGB proteins are necessary for cell-to-cell movement, whereas viruses encoding potexlike TGB also require coat protein (CP) for their intercellular transport (Chapman et al. 1992; Fedorkin et al. 2001; Forster et al. 1992; Krishnamurthy et al. 2002).

Phylogenetically, TGBp1 is a diverged duplicate of the viral replication-related NTPase/helicase, whereas TGBp2 and TGBp3 are small hydrophobic proteins (Morozov et al. 1989; Morozov and Solovyev 2003; Solovyev et al. 1996). TGBp1s of both groups have NTPase, helicase, and RNA-binding activities (Bleykasten et al. 1996; Cowan et al. 2002; Donald et al. 1997; Erhardt et al. 2000; Kalinina et al. 1996, 2001, 2002; Lough et al. 1998; Rouleau et al. 1994; Wung et al. 1999). Although the biological role of the NTPase and helicase activities of TGBp1 remains a subject of speculation, RNA binding is believed to be necessary for formation of complexes with viral genomic RNAs, or ribonucleoproteins (RNPs), which represent the movement-competent form of the virus genome (Morozov and Solovyev 2003; Oparka 2004).

Fractionation studies of PMTV-infected tissues revealed that TGBp1 partitions into the membrane (P1 and P30) and cell wall fractions (Cowan et al. 2002). Similar subcellular distribution was found for TGBp1 of Peanut clump virus (PCV, genus Pecluvirus) (Erhardt et al. 1999b). Immunogold labeling and electron microscopy of PCV-infected tissues demonstrated localization of TGBp1 in plasmodesmata, whereas the transgenically expressed PCV TGBp1 exhibited no association with plasmodesmata (Erhardt et al. 1999b). However, when the same transgenic plants were infected with TGBp1-deficient PCV, TGBp1 was localized to plasmodesmata (Erhardt et al. 1999b). These data provided the first indication that subcellular localization of the hordei-like TGBp1 is determined by other viral products. Experiments on chimeric rod-shaped viruses demonstrated that TGBp1 requires homologous TGBp2 and TGBp3 to direct virus spread (Erhardt et al. 1999a; Lauber et al. 1998; Solovyev et al. 1999). The possible role of TGBp2 and TGBp3 in localization of TGBp1 was verified using modified viral genomes expressing TGBp1 fused with the green fluorescent protein 
(GFP). In infected leaf cells, GFP-TGBp1 of Beet necrotic yellow vein virus (BNYVV, genus Benyvirus) and Barley stripe mosaic virus (BSMV, genus Hordeivirus) localized in punctate bodies at the cell periphery (Erhardt et al. 2000; Lawrence and Jackson 2001). Moreover, TGBp1-containing structures were co-localized with callose (Erhardt et al. 2000) consistent with previous observations on localization of TGBp1 in plasmodesmata of infected leaves (Erhardt et al. 1999b). Site-directed mutagenesis disrupting TGBp2, TGBp3, or both demonstrated that, in the absence of either one or both of these proteins, BNYVV GFP-TGBp1 was not localized to plasmodesmata-associated sites showing a uniform subcellular distribution (Erhardt et al. 2000). Similarly, targeting of GFP-TGBp1 to discrete bodies near the plasma membrane of BSMV-infected protoplasts required both TGBp2 and TGBp3 (Lawrence and Jackson 2001).

Studies of hordei-like TGBp2 and TGBp3 fused to fluorescent reporter proteins demonstrated that, when TGBp2 was expressed alone, it was distributed throughout the cell endomembrane network, mostly the cortical endoplasmic reticulum (ER). TGBp3 was localized in peripheral membrane bodies, which are derivatives of ER structures associated with plasmodesmal neck regions (Cowan et al. 2002; Gorshkova et al. 2003; Solovyev et al. 2000; Zamyatnin et al. 2002). Importantly, co-expression of TGBp2 and TGBp3 resulted in redirection of TGBp2 from the ER network to the TGBp3-containing peripheral bodies (Solovyev et al. 2000; Zamyatnin et al. 2002). In potex-like TGB, both TGBp2 and TGBp3 were reported to be associated with ER structures (Krishnamurthy et al. 2003; Mitra et al. 2003).

In this study, we employed particle bombardment for transient expression of PMTV TGB proteins in leaf epidermal cells and used fluorescent microscopy for protein localization to reconstruct the natural process of inter- and intracellular transport of PMTV TGBp1. This approach allowed us to analyze early events of viral cell-to-cell movement taking place immediately after the synthesis of movement proteins in the initially infected cell. Our results show that TGBp2 and TGBp3 direct TGBp1 to intermediate bodies and smaller, cell wall-embedded punctate bodies, and mediate transport of
TGBp1 through plasmodesmata. Additionally, site-directed mutagenesis was used to identify the regions of TGB proteins involved in different stages of TGBp1 transport.

\section{RESULTS}

Subcellular targeting and cell-to-cell movement of PMTV GFP-TGBp1 depend on TGBp2 and TGBp3.

To examine the subcellular distribution of PMTV TGBp1, we fused the GFP gene to the 5' end of TGBp1 gene and placed this fusion under control of the Cauliflower mosaic virus $35 \mathrm{~S}$ promoter (construct pRT-GFP-TGBp1) (Fig. 1). The fusion protein was transiently expressed in epidermal cells of Nicotiana benthamiana leaves by particle bombardment. Confocal laser scanning microscopy (CLSM) of the bombarded leaves revealed that PMTV GFP-TGBp1 was distributed in the cytosol and the nuclei (Fig. 2B), closely resembling localization of free GFP (Fig. 2A). Similar subcellular distribution has been described for GFP-fused TGBp1 of BSMV (Lawrence and Jackson 2001).

The influence of other TGB proteins on the subcellular localization of PMTV TGBp1 was tested by coexpression of GFP-TGBp1 with TGBp2 and TGBp3. A bicistronic expression vector pRT-TGBp2/TGBp3 (Fig. 1) that directs the synthesis of mRNA similar to the natural template for translation of TGBp2 and TGBp3 (Morozov and Solovyev 2003) was used in this experiment. For co-bombardment of leaves, a mixture of plasmids was precipitated on the tungsten particle surface in equimolar ratio. Previous experiments demonstrated that such an approach ensures the delivery of both expression vectors in all cells transformed by particle bombardment (Solovyev et al. 2000; Zamyatnin et al. 2002). CLSM of $N$. benthamiana leaves co-bombarded with pRT-GFP-TGBp1 and pRT-TGBp2/TGBp3 revealed that the subcellular distribution of GFP-TGBp1 was altered in the presence of TGBp2 and TGBp3 (Fig. 2D and E). A minor portion of GFP-TGBp1 remained in the cytoplasm and the nucleus, while most of the fusion protein was associated with two distinct types of subcellular structures never observed in the cells expressing GFPTGBp1 only. The fusion protein was located in large plasma
pRT-GFP-TGBp1

pRT-TGBp2/TGBp3

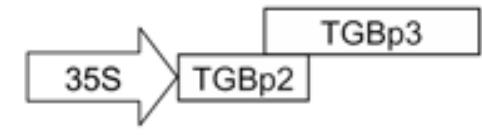

pRT-TGBp2

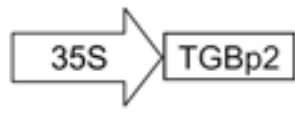

pRT-TGBp3
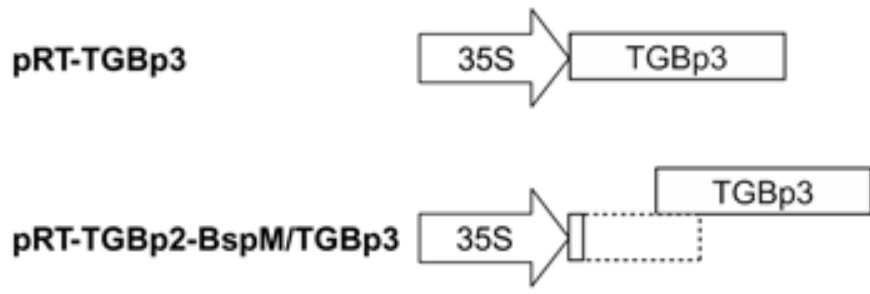

Fig. 1. Schematic presentation of the plasmids for transient expression of green fluorescent protein (GFP)-triple gene block (TGB)p1, TGBp2, and TGBp3. Genes are shown as boxes. The box drawn by a dashed line shows an untranslated out-of-frame portion of TGBp2 gene in pRT-TGBp2-BspM/TGBp3. 35S $=35 \mathrm{~S}$ promoter of Cauliflower mosaic virus. 
membrane-proximal bodies (called hereafter "intermediate bodies") extended along cell borders and in cell wall-embedded punctate bodies (Fig. 2D and E). The latter structures were similar to those described for GFP fusions of several plas- modesmata-targeted plant proteins such as a Rab11 homologue PD10 and an unknown protein PD08 (Escobar et al. 2003), and the Tobacco mosaic virus movement protein (Oparka and Roberts 2001).
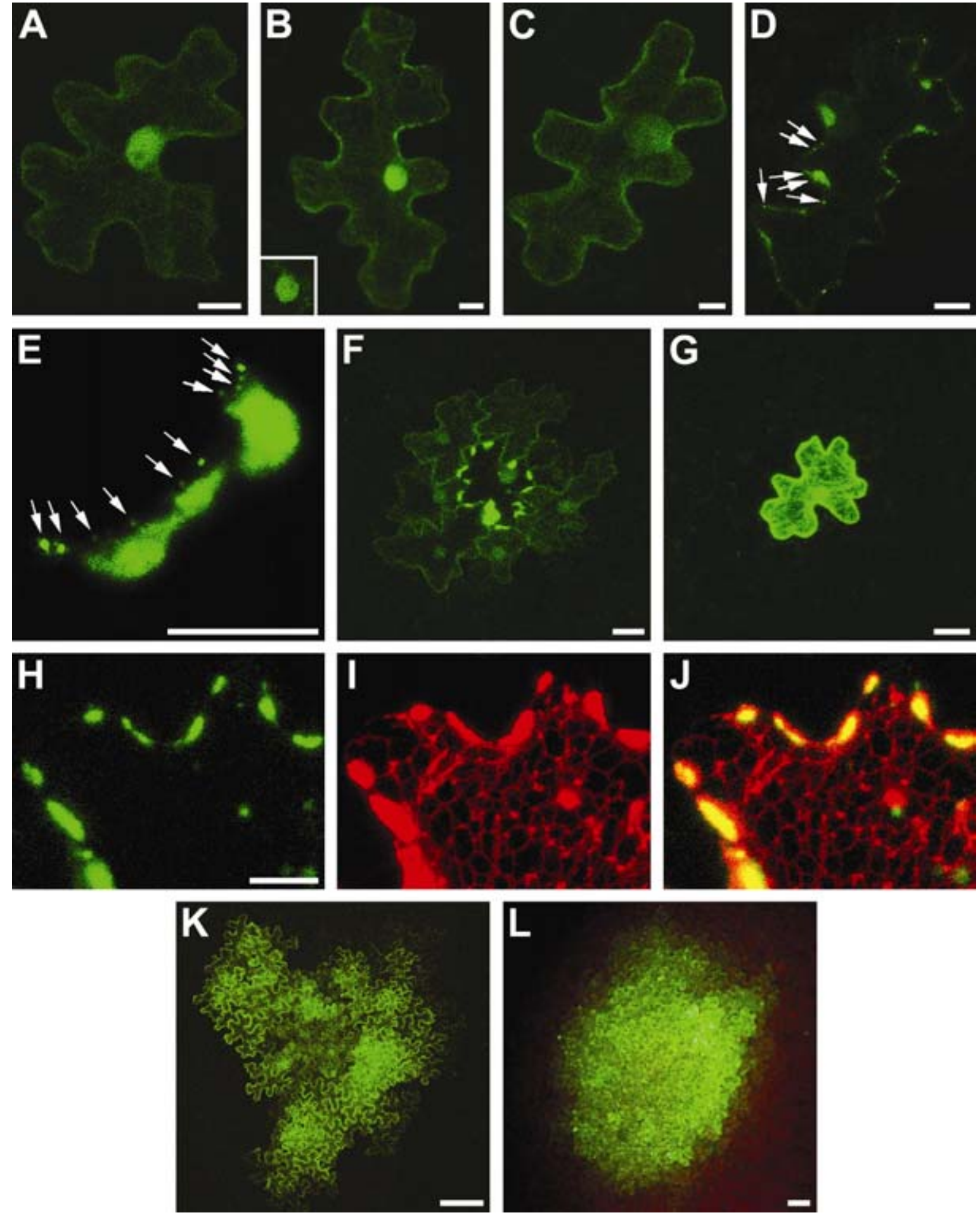

Fig. 2. Confocal laser scanning microscopy images of bombarded Nicotiana benthamiana epidermal cells showing localization of green fluorescent protein (GFP)-triple gene block (TGB)p1. A, Cell expressing GFP. B, Expression of Potato mop-top virus (PMTV) GFP-TGBp1. Inset represents single optical section through the middle of the nucleus. C, Coexpression of PMTV GFP-TGBp1 and TGBp2-BspM/TGBp3. D, Coexpression of PMTV GFP-TGBp1 and TGBp2/TGBp3. Arrows point to cell wall-embedded punctate bodies. E, Image of higher magnification representing part of the cell coexpressing PMTV GFP-TGBp1 and TGBp2/TGBp3. Arrows point to cell wall-embedded punctate bodies. F, Low-magnification image of the cell coexpressing PMTV GFPTGBp1 and TGBp2/TGBp3. Laser power used for GFP excitation in F and $\mathrm{G}$ was approximately 10-fold higher than in A through D. G, Low-magnification image of leaf tissue bombarded by the PMTV GFP-TGBp1 construct. $\mathbf{H}$ through $\mathbf{J}$, Coexpression of endoplasmic reticulum (ER)-targeted yellow fluorescent protein (YFP-ER) with GFP-TGBp1 and TGBp2/TGBp3. H, Localization of GFP-TGBp1. A narrow acquisition window of GFP signal, required for two-color imaging of GFP and YFP, prevented visualization of cell wall-embedded punctate structures in this experiment. I, Localization of YFP-ER. YFP fluorescence is shown in red. J, Superposition of images in $\mathbf{H}$ and I. $\mathbf{K}$ and $\mathbf{L}$, Detection of GFP-TGBp1 fluorescence in the developing PMTV infection foci on $\mathbf{K}, 3$ and $\mathbf{L}, 5$ days postinoculation. Note: magnification of $\mathrm{K}$ is twice that of $\mathrm{L}$. Scale bars: F and $\mathrm{G}, 20 \mu \mathrm{m} ; \mathrm{K}$ and $\mathrm{L}, 100 \mu \mathrm{m}$; all other panels, $10 \mu \mathrm{m}$. 
To analyze the possible relation of GFP-TGBp1-containing intermediate bodies to the ER structures, we visualized ER using YFP-ER, a yellow fluorescent protein (YFP) derivative containing the $\mathrm{N}$-terminal signal sequence of Arabidopsis thaliana basic chitinase and C-terminal ER-retention signal (Haseloff et al. 1997). In $N$. benthamiana leaves bombarded with pRT-YFP-ER, YFP fluorescence was confined to ER (data not shown). In co-bombardment experiments with pRTYFP-ER, pRT-GFP-TGBp1, and pRT-TGBp2/TGBp3, all GFP-TGBp1-containing intermediate bodies also contained ER-targeted YFP and seemed to be connected to the cortical ER network (Fig. 2H through J). These data indicate an ER origin of intermediate bodies, suggesting their similarity to peripheral bodies formed by hordeiviral TGBp3 (Gorshkova et al. 2003; Zamyatnin et al. 2002).

No cell-to-cell movement of GFP-TGBp1 was detected when it was expressed alone (Fig. 2G). Coexpression of
TGBp2 and TGBp3 with GFP-TGBp1 resulted in efficient transport of GFP-TGBp1 to the neighboring cells (Fig. 2F) in more than $75 \%$ of the transfected foci (46 of 60 foci observed). Importantly, GFP-TGBp1 was transported only to the cells immediately adjacent to the transfected cell ('secondary cells'). Furthermore, subcellular localization of GFP-TGBp1 in secondary cells clearly differed from the transfected cells (Fig. 2F) and was similar to the cells expressing GFP-TGBp1 only (Fig. 2, compare F to B). In a control experiment, GFP was coexpressed with PMTV TGBp2 and TGBp3. In this case, diffusion of GFP to the neighboring cells was observed only in $13 \%$ of the fluorescent foci ( 8 of 60 foci observed). The level of GFP diffusion could depend significantly on a leaf physiological status (sink or source) (Zambryski 2004). However, leaves of the same age were used for bombardment with GFP and GFP-TGBp1 constructs; therefore, the considerable difference in percentage of foci showing protein egress from initial
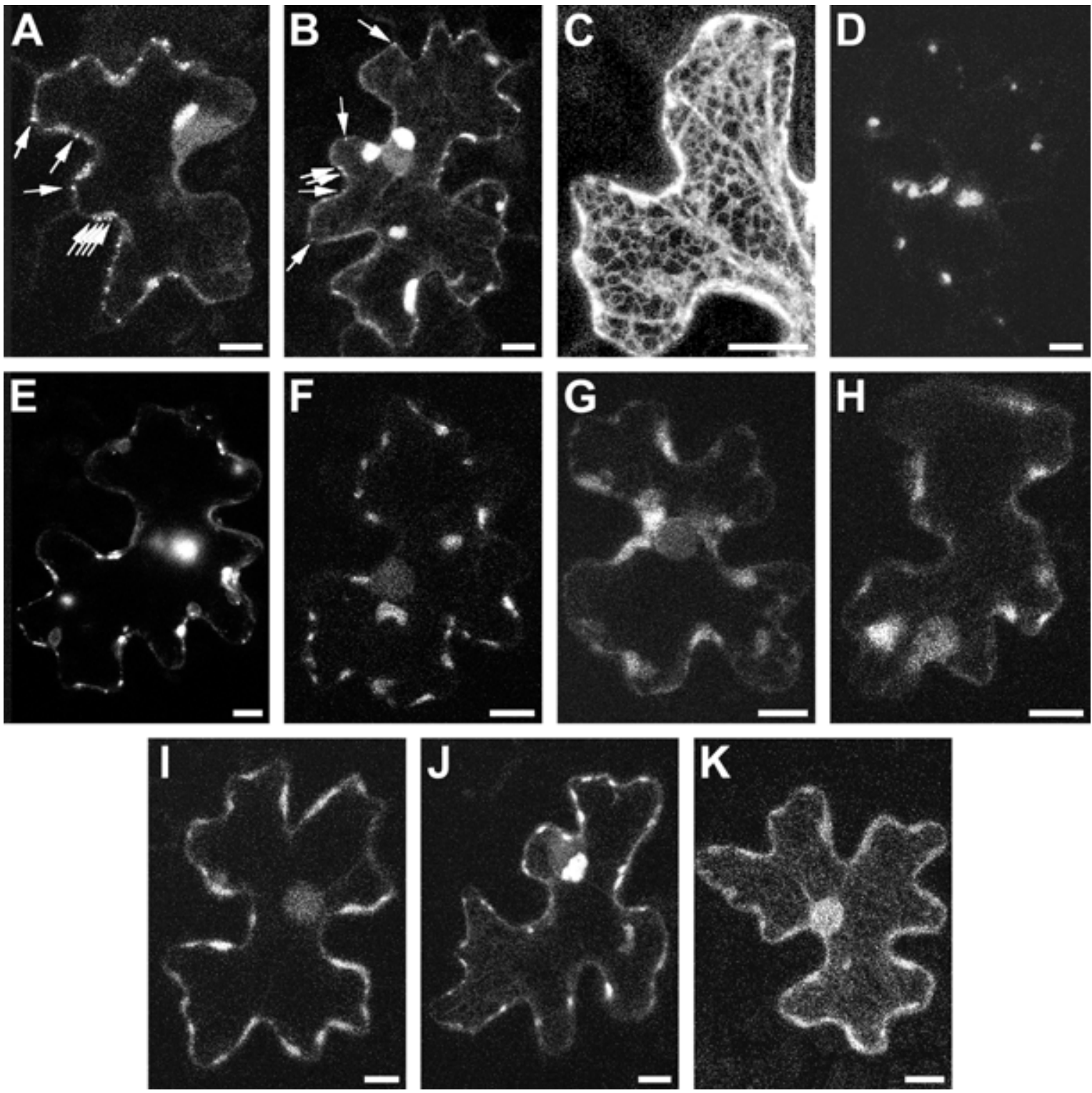

Fig. 3. Confocal laser scanning microscopy images of Nicotiana benthamiana epidermal cells bombarded by green fluorescent protein (GFP) fusion constructs of triple gene block (TGB) genes. $\mathbf{A}$ and $\mathbf{B}$, Coexpression of Potato mop-top virus (PMTV) GFP-TGBp1 with PMTV TGBp2 and TGBp3 expressed from separate vectors: A, pRT-TGBp2 and pRT-TGBp3 or B, pRT-TGBp2 and pRT-TGBp2-BspM/TGBp3. Arrows point to cell wall-embedded punctate bodies. C, Cell expressing PMTV GFP-TGBp2. D, Coexpression of PMTV GFP-TGBp2 with PMTV TGBp3. E, Coexpression of PMTV GFPTGBp2 and Poa semilatent virus (PSLV) TGBp3. F-K, PMTV GFP-TGBp1 is coexpressed with heterologous TGBp2, TGBp3, or both: F, PMTV TGBp2 and PSLV TGBp3; G, PSLV TGBp2 and PMTV TGBp3; H, PSLV TGBp2/TGBp3; I, PMTV TGBp2 and Potato virus X (PVX) TGBp3; J, PVX TGBp2 and PMTV TGBp3; and K, PVX TGBp2/TGBp3. Scale bars represent $10 \mu \mathrm{m}$. 
cells was taken as an indication of active GFP-TGBp1 cell-tocell transport.

To analyze whether both TGBp2 and TGBp3 affected TGBp1 localization, pRT-GFP-TGBp1 was first co-bombarded with pRT-TGBp2 only (Fig. 1). CLSM of $N$. benthamiana leaves revealed that TGBp2 alone did not affect subcellular localization of GFP-TGBp1 and was unable to facilitate cell-to-cell movement of TGBp1 (data not shown). Similar results were obtained with TGBp3, regardless of whether pRT-TGBp2-BspM/TGBp3 (Fig. 1), which contains a frameshift mutation in the beginning of the open reading frame for TGBp2, or pRT-TGBp3 (Fig. 1) were used for co-bombardment with pRT-GFP-TGBp1 (Fig. 2C and data not shown). Therefore, both TGBp2 and TGBp3 are required for subcellular targeting of TGBp1 to the peripheral structures and its translocation to adjacent cells. However, expression of TGBp2 and TGBp3 from a bicistronic mRNA was not required for TGBp1 trafficking; that was inferred from experiments with TGBp2 and TGBp3 expressed from separate constructs. Indeed, co-bombardment of pRT-GFP-TGBp1 with pRT-TGBp2 and either pRT-TGBp3 or TGBp2-BspM/TGBp3 (Fig. 1) resulted in TGBp1 localization similar to that in cells co-bombarded with pRT-GFP-TGBp1 and pRT-TGBp2/TGBp3 (Fig. 3A and B).

Thus, the transient coexpression of GFP-TGBp1 with TGBp 2 and TGBp3 revealed three potential stages and targets of TGBp1 translocation: association with plasma membraneproximal intermediate bodies, trafficking to the cell wallembedded punctate bodies presumably localized inside plasmodesmata, and movement into adjacent cells.

To test the biological activity of GFP-TGBp1 fusion protein, its gene was used to replace the TGBpl gene in a PMTV RNA3 full-length cDNA clone (Savenkov et al. 2003). In vitro transcripts of the resulting clone (pPMTV3-GFP-TGBp1) along with the transcripts for RNA1 and RNA2 were inoculated onto $N$. benthamiana plants. At 3 days postinoculation, analysis of inoculated leaves revealed fluorescent sites of infection (Fig. 2K) which later expanded radially (Fig. 2L). These data show that GFP-TGBp1 fusion is functionally active in the context of viral genome.

\section{Targeting of TGBp1 by heterologous TGBp2 and TGBp3.}

The TGBp3-directed subcellular sorting of TGBp2 occurs in a sequence-nonspecific manner (Solovyev et al. 2000; Zamyatnin et al. 2002). To test whether the TGBp2- and

Table 1. Localization of green fluorescent protein (GFP)-triple gene block (TGB)p1 coexpressed with heterologous TGBp2 and TGBp3

\begin{tabular}{llc}
\hline $\begin{array}{l}\text { Proteins coexpressed } \\
\text { with TGBp1 }^{\mathbf{a}}\end{array}$ & $\begin{array}{c}\text { Distribution } \\
\text { phenotype }^{\mathbf{b}}\end{array}$ & $\begin{array}{c}\text { Cell-to-cell } \\
\text { transport }^{\mathbf{c}}\end{array}$ \\
\hline None & $\mathrm{C}+\mathrm{N}$ & - \\
PMTV TGBp2/TGBp3 & $\mathrm{C}+\mathrm{N}+\mathrm{IB}+\mathrm{PB}$ & + \\
PMTV TGBp2 + PSLV TGBp3 & $\mathrm{C}+\mathrm{N}+\mathrm{IB}$ & - \\
PSLV TGBp2 + PMTV TGBp3 & $\mathrm{C}+\mathrm{N}+\mathrm{IB}$ & - \\
PSLV TGBp2/TGBp3 & $\mathrm{C}+\mathrm{N}+\mathrm{IB}$ & - \\
PMTV TGBp2 + PVX TGBp3 & $\mathrm{C}+\mathrm{N}+\mathrm{IB}$ & - \\
PVX TGBp2 + PMTV TGBp3 & $\mathrm{C}+\mathrm{N}+\mathrm{IB}$ & - \\
PVX TGBp2/TGBp3 & $\mathrm{C}+\mathrm{N}+\mathrm{IB}$ & - \\
PMTV TGBp2 + BNYVV TGBp3 & $\mathrm{C}+\mathrm{N}+\mathrm{IB}$ & - \\
\hline
\end{tabular}

a TGBp2/TGBp3 indicates that a bicistronic expression vector for TGBp2 and TGBp3 was used.

${ }^{\mathrm{b}} \mathrm{C}=$ cytoplasm, $\mathrm{N}=$ nucleus, $\mathrm{IB}=$ intermediate bodies, $\mathrm{PB}=$ cell wallembedded punctate bodies.

c Cell-to-cell transport of GFP-TGBp1 was detected in $75 \%$ of transfected foci (46 of 60 foci observed) (+). In contrast, in control coexpression of nonfused GFP with TGBp2 and TGBp3, cell-to-cell movement was detected only in $13 \%$ of transfected foci ( 8 of 60 foci observed) (-).

${ }^{\mathrm{d}}$ Efficiency of GFP-TGBp1 translocation to IB was much lower compared with the other experiments.
TGBp3-directed targeting and cell-to-cell movement of TGBp1 is also sequence nonspecific, we used transient coexpression of PMTV TGB proteins with the heterologous TGBp2 and TGBp3 of BNYVV, Poa semilatent virus (PSLV, genus Hordeivirus), or Potato virus $X$ (PVX, genus Potexvirus). TGBp3 of PSLV, PVX, and BNYVV efficiently directed the transport of PMTV GFP-TGBp2 from the ER network, its typical site of localization (Cowan et al. 2002) (Fig. 3C), to the peripheral membrane bodies characteristic of TGBp3 (Fig. 3D and E; data not shown) (Solovyev et al. 2000).

When GFP-TGBp1 was coexpressed with PMTV TGBp2 and the TGBp3 of PSLV, PVX, or BNYVV, only trace amounts of fluorescence remained in cytoplasm and nucleus, whereas most of the GFP-tagged protein was localized in the intermediate bodies (Table 1; Fig. 3F and I; data not shown). Similar subcellular distribution of GFP-TGBp1 was found when TGBp2 of either PSLV or PVX was coexpressed with PMTV GFP-TGBp1 and TGBp3 (Fig. 3G and J; Table 1) or when PMTV GFP-TGBp1 was coexpressed with TGBp2 and TGBp3 encoded by one of the heterologous viruses (PSLV or PVX) (Table 1; Fig. 3J and K). However, a smaller proportion of GFP-TGBp1 was directed to intermediate bodies by PVX TGBp2 and TGBp3 than PSLV TGBp2 or TGBp3 (Fig. 3, K compared with J). In these experiments, the fluorescent structures inside the cell walls and the cell-to-cell transport of TGBp1 were not found. Thus, localization of PMTV GFPTGBp1 inside the cell walls and translocation to adjacent cells required cognate TGBp2 and TGBp3.

\section{Regions of TGBp1 important for targeting mediated by TGBp2 and TGBp3.}

Similar to other hordei-like TGBp1 proteins, PMTV TGBp1 contains two structural domains: the C-terminal NTPase/helicase domain with seven conserved motifs and the $\mathrm{N}$-terminal extension domain (Fig. 4A) (Morozov and Solovyev 2003). To determine involvement of different TGBp1 regions in the TGBp2- and TGBp3-mediated trafficking of TGBp1, three mutations were introduced into pRT-GFP-TGBp1. First, a region coding for 49 amino acids (aa) between a positively charged stretch at the $\mathrm{N}$-terminus and the helicase domain was deleted (mutant GFP-TGBp1-Mlu1) (Fig. 4A). To disable functional activities of the helicase domain, the sequence GSGKT in the conserved motif I (Morozov and Solovyev 2003) was replaced by the sequence SSAAT (mutant GFP-TGBp1-GKT) (Fig. 4A). In the third mutant, a region including conserved helicase motifs $\mathrm{V}$ and VI was deleted (mutant GFP-TGBp1-delC) (Fig. 4A). Individually expressed mutants were found to be distributed similarly to the wild-type GFP-TGBp1 (data not shown). Co-bombardment experiments were carried out with the mutated GFPTGBp1 and the constructs expressing PMTV TGBp2 and TGBp3. CLSM revealed that GFP-TGBp1-Mlu1 behaved similarly to GFP-TGBp1 when coexpressed with TGBp2 and TGBp3. It was localized to the intermediate bodies, cell wallembedded punctate bodies, and in the adjacent cells (Fig. 4C). GFP-TGBp1-GKT was found mainly in the intermediate bodies. However, it was not detected in the cell wall-embedded punctate bodies and in the neighboring cells (Fig. 4D). Unlike other TGBp1 mutants, localization of GFP-TGBp1-delC was not altered when this mutant was coexpressed with PMTV TGBp2 and TGBp3 (Fig. 4E). These data showed that the distinct sequence elements of TGBp1 differently affect its targeting by TGBp2 and TGBp3.

\section{TGBp2 and TGBp3 sequences involved in TGBp1 targeting.}

Regions of TGBp2 and TGBp3 involved in the targeting of TGBp1 were mapped using a series of mutants based on the 
A
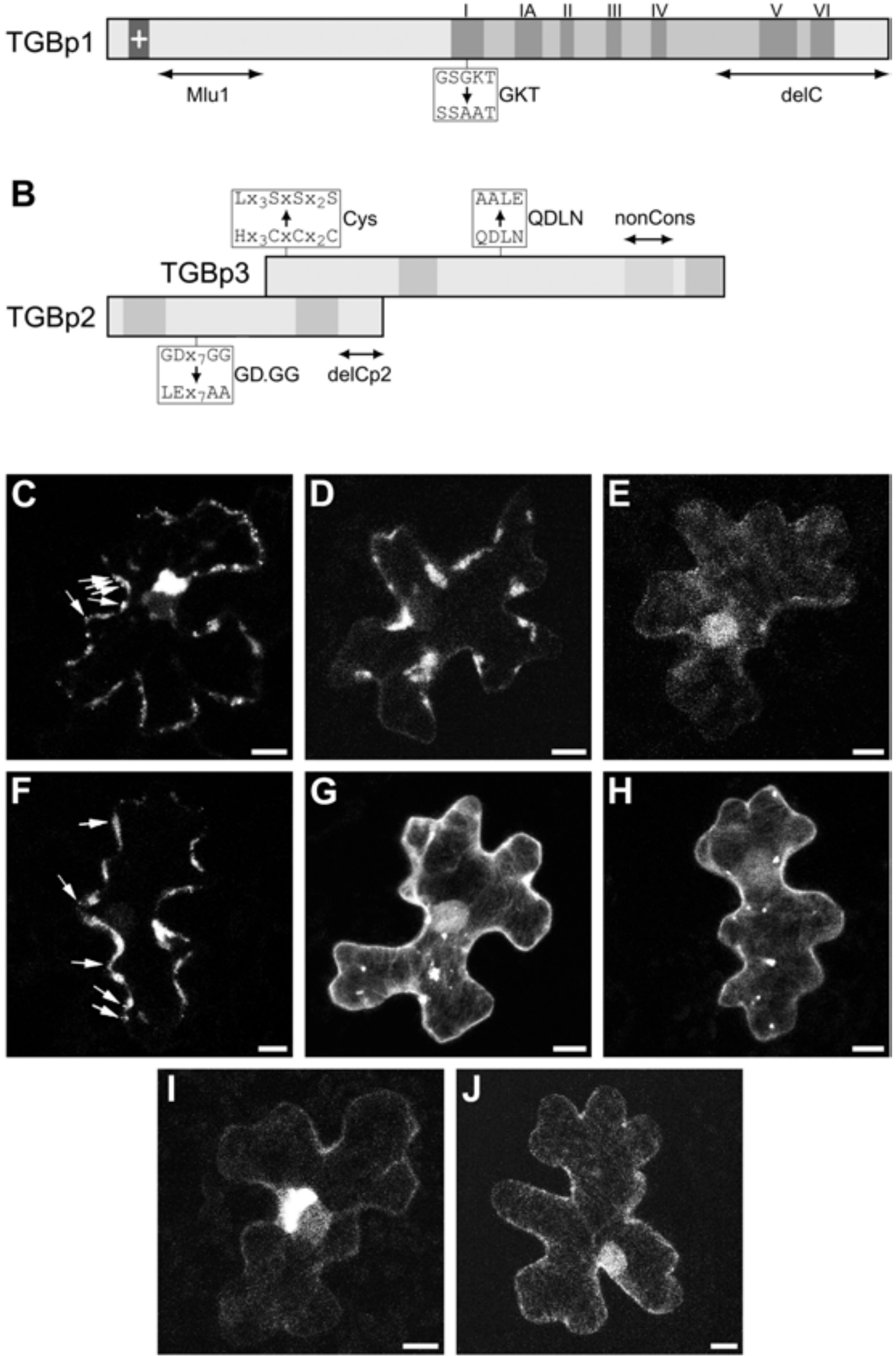

Fig. 4. Schematic presentation of mutations introduced in A, triple gene block (TGB)p1 and $\mathbf{B}$, TGBp2/TGBp3. Horizontal arrows indicate deletions in $\mathbf{A}$, green fluorescent protein (GFP)-TGBp1-Mlu1 and GFP-TGBp1-delC and B, TGBp2-delCp2/TGBp3 and TGBp2/TGBp3-nonCons. The original sequences and the mutated sequences resulting from point substitutions of the conserved amino acids in A, GFP-TGBp1-GKT and B, TGBp2-GD.GG/TGBp3, TGBp2/TGBp3-Cys, and TGBp2/TGBp3-QDLN are shown in boxes. C through J, Confocal laser scanning microscopy images of transfected Nicotiana benthamiana epidermal cells expressing the mutant proteins. Images of the cells coexpressing TGBp2/TGBp3 and C, GFP-TGBp1-Mlu1, D, GFP-TGBp1GKT, or E, GFP-TGBp1-delC; cells coexpressing GFP-TGBp1 and F, TGBp2/TGBp3-nonCons, G, TGBp2-GD.GG/TGBp3, H, TGBp2/TGBp3-QDLN, I, TGBp2/TGBp3-Cys, or J, TGBp2-delCp2/TGBp3. Arrows in A and D point to cell wall-embedded punctate bodies. Scale bars represent $10 \mu \mathrm{m}$. 
bicistronic construct pRT-TGBp2/TGBp3 (Fig. 1). In TGBp2GD.GG/TGBp3, site-directed mutations altered the invariant residues in the central conserved region of TGBp2 (Fig. 4B). TGBp2-delCp2/TGBp3 contained a point mutation introducing a stop codon, which resulted in synthesis of TGBp2 with a 20-aa deletion from the C-terminus (Fig. 4B). TGBp2/TGBp3Cys contained point mutations of the invariant histidine and

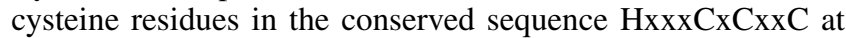
the N-terminus of TGBp3 (Fig. 4B). The highly conserved central region of TGBp3 with characteristic signature QDLN (Solovyev et al. 1996) was mutated in TGBp2/TGBp3-QDLN (Fig. 4B).

Co-bombardment of $N$. benthamiana leaves with pRT-GFPTGBp1 and pRT-TGBp2-delCp2/TGBp3 (Fig. 4B) caused no alteration in the localization of GFP-TGBp1, compared with cells expressing GFP-TGBp1 only (Figs. 4J and 2B). Therefore, the $20 \mathrm{C}$-terminal amino acids at TGBp2 are indispensable to the trafficking of TGBp1 directed by TGBp2 and TGBp3. In cells coexpressing GFP-TGBp1 and either TGBp2GD.GG/TGBp3 or TGBp2/TGBp3-QDLN, fluorescence was associated with the cytoplasm, nucleus, and multiple inclusion bodies of different sizes (Fig. 4G and $\mathrm{H}$ ). Coexpression of GFP-TGBp1 with TGBp2/TGBp3-Cys resulted in localization of TGBp1 to one or few large, amorphous inclusions in the cell (Fig. 4I). Taken together, these results suggest that mutations in TGBp2 or TGBp3 may inhibit the interactions with TGBp1 and their subcellular trafficking to peripheral compartments.

In pomoviruses, the central hydrophilic region of TGBp3 contains an "insertion" of 13- to 30-aa residues, which is not found in members of the Hordeivirus and Pecluvirus genera (Solovyev et al. 1996). Furthermore, this unique region is the most variable part of the pomoviral TGBp3 (Koenig et al. 1996; Lu et al. 1998; Scott et al. 1994). In the mutant TGBp2/TGBp3-nonCons, 25 aa were removed from the unique region of PMTV TGBp3 (Fig. 4B). Co-bombardment of this mutant with pRT-GFP-TGBp1 revealed the same distribution of GFP fluorescence as in cells coexpressing GFPTGBp1 and intact TGBp2 and TGBp3 (Fig. 4F). Moreover, transport of GFP-TGBp1 to adjacent cells also was observed (data not shown). To examine the possible role of the TGBp3 insertion sequence in PMTV infection, it was deleted from the cDNA clone of RNA3 (pPMTV-3) (Savenkov et al. 2003). In vitro transcripts of this clone along with the transcripts of the full-length cDNA clones of PMTV genomic RNA1 and RNA2 (Savenkov et al. 2003) were inoculated onto $N$. benthamiana plants. The mutant virus retained the wild-type infection and symptom phenotypes (data not shown). In contrast, similar tests with other TGB mutants introduced into PMTV RNA3 (pPMTV-3-GKT, pPMTV-3-GD.GG, pPMTV-3-delCp2, pPMTV-3-Cys, or pPMTV-3-QDLN) (Fig. 4A and B) showed the inability of the mutant viruses to infect $N$. benthamiana (data not shown).

\section{DISCUSSION}

Functional interactions between TGBp1 and the two other TGB proteins (TGBp2 and TGBp3) may be essential for viral cell-to-cell movement (Morozov and Solovyev 2003). In this study, we used PMTV TGB proteins as a model to get insight into the concerted activities of TGBp1 with TGBp2 and TGBp3.

When expressed alone, PMTV TGBp1 was distributed throughout the cytoplasm and nucleus with no preference to any particular cellular compartment and was restricted to the transfected cell. However, coexpression with TGBp2 and TGBp3 resulted in a different distribution of TGBp1. It was found in intermediate bodies representing elongated plasma membrane- proximal structures, which seemed to be connected to the cortical ER network (Fig. 2). Intermediate bodies were very similar to the previously described GFP-TGBp3-formed peripheral bodies localized to cortical ER near plasmodesmal orifices (Gorshkova et al. 2003; Solovyev et al. 2000; Zamyatnin et al. 2002). TGBp3 is known to direct GFP-fused TGBp2 to these bodies (Fig. 3D) (Zamyatnin et al. 2002). It can be speculated that TGBp1 also is bound to TGBp3-induced structures in the presence of TGBp2 and TGBp3. This is supported by previous findings showing that, in cells infected with BNYVV and BSMV, the two smaller TGB proteins (TGBp2 and TGBp3) are required for TGBp1 transport to peripheral plasmodesmata-related structures (Erhardt et al. 2000; Lawrence and Jackson 2001).

Furthermore, PMTV TGBp1 coexpressed with TGBp2 and TGBp3 was localized to cell wall-embedded punctate bodies. These structures were similar to the bodies in the central cavity of plasmodesmata formed by Tobacco mosaic virus movement protein and plasmodesmata-targeted cellular proteins (Escobar et al. 2003; Oparka and Roberts 2001). Similar structures also were reported for the cells infected with BNYVV that express a GFP-TGBp1 fusion protein (Erhardt et al. 2000).

Coexpression of GFP-TGBp1 with TGBp2 and TGBp3 resulted in cell-to-cell transport of TGBp1 from the transfected cell to the adjacent cells. Importantly, TGBp1 was transported only to the cells immediately adjacent to the transfected cell. In these secondary cells, subcellular localization of the GFPTGBp1 differed from the transfected cell. No cell wall-associated structures were found, and the distribution of GFP fluorescence was similar to the cells expressing GFP-TGBp1 only. These data suggest that TGBp2, TGBp3, or both were not transported with TGBp1 to the adjacent cells. Furthermore, these findings indicate as well that TGBp 2 and TGBp 3 mRNA is not transported to the secondary cells, which allowed us to propose that the observed localization of GFP-fused TGBp1 in secondary cells reflected intercellular transport of the protein itself rather than its mRNA. These conclusions are supported by previous studies showing that cell-to-cell movement of potexviral genomes, transport deficient due to mutations in either TGBp 2 or TGBp3, can be complemented by co-bombardment with the plasmids expressing the respective functional proteins, which mediate viral cell-to-cell movement only to the cells neighboring the transfected cell (Lough et al. 2000; Tamai and Meshi 2001). These observations have prompted us to hypothesize that, although TGBp2 and TGBp3 cannot exit the infected cell, their functions are crucial for intracellular delivery of TGBp1-containing RNPs to plasmodesmata for cellto-cell translocation of the virus genome (Lough et al. 1998, 2000; Morozov and Solovyev 2003; unpublished data).

Unlike TGBp1 of PMTV and other viruses with hordei-like TGB that require both TGBp2 and TGBp3 for TGBp1 transport to the cell wall-associated sites (this study; Erhardt et al. 1999b, 2000; Lawrence and Jackson 2001), potexviral TGBp1 can move to and through plasmodesmata in the absence of TGBp2 and TGBp3 (Lough et al. 1998, 2000; Yang et al. 2000). Perhaps the hordei-like TGBp1, being approximately twice as large as the potex-like TGBp1, is more dependent on auxiliary functions provided by TGBp2 and TGBp3 for its translocation into plasmodesmal microchannels.

TGBp3 can target homologous and heterologous TGBp2 to peripheral bodies (Fig. 3) (Solovyev et al. 2000; Zamyatnin et al. 2002). This study showed that heterologous TGBp3 and TGBp2 of PSLV, PVX, and BNYVV directed PMTV TGBp1 to the intermediate bodies, but not to the cell wall-embedded punctate bodies and the adjacent cells (Table 1; Fig. 3). These findings suggest that the heterologous TGBp3 proteins could facilitate intracellular trafficking of PMTV TGBp1 to the plas- 
modesmal neck regions. However, they are not competent to mediate subsequent transport of TGBp1 into and through plasmodesmata. This agrees with previous data showing that only a complete set of TGB proteins encoded by the same virus is competent for the cell-to-cell movement functions (Erhardt et al. 1999a; Lauber et al. 1998; Solovyev et al. 1999).

Coexpression of GFP-TGBp1 with TGBp2 and TGBp3, in which the invariant amino acid residues were substituted, resulted in the appearance of aberrant GFP-TGBp1-containing intracellular aggregates and inhibition of transport of GFPTGBp1 to the intermediate bodies (Fig. 4). These findings are in accordance with the theory that mutations within conserved amino acid residues of TGBp2 and TGBp3 affect intracellular transport of the putative membrane vesicles bound to TGBp1 (Morozov and Solovyev 2003) rather then their formation. However, deletion of C-terminal hydrophilic region of TGBp2 prevented detectable compartmentalization of GFP-TGBp1 fluorescence, which suggests that the $\mathrm{C}$-terminal hydrophilic region of TGBp2 may be directly involved in the interactions of TGBp2 with TGBp1 or a TGBp1-containing RNP (Brakke et al. 1988; Cowan et al. 2002; Morozov and Solovyev 2003).

Mutations in the conserved regions of the NTPase/helicase domain of PMTV TGBp1 inhibited localization of GFPTGBp1 to cell wall-embedded punctate bodies and cell-to-cell translocation of GFP-TGBp1, as found in previous studies with other viruses (Erhardt et al. 2000; Lawrence and Jackson 2001). However, a mutation in the conserved motif I of the NTPase/helicase domain, which abolishes the NTPase and unwinding activities of the helicases (Caruthers and McKey 2002; Geourjon et al. 2001), had no effect on formation of the intermediate bodies. These data suggest that NTPase/helicase activity is not essential for intracellular trafficking of TGBp1 by TGBp2 and TGBp3.

Deletion of the conserved motifs V and VI of the helicase domain in TGBp1 inhibited formation of intermediate bodies and intracellular inclusions of any kind, which could be explained by blocked association of TGBp1 with the hypothesized specific for TGBp2 and TGBp3 membrane vesicles (Morozov and Solovyev 2003). This is supported by the previous findings suggesting that the PVX TGBp1 region containing the conserved motifs $\mathrm{V}$ and VI is involved in protein-protein interactions (Morozov et al. 1999). On the other hand, our results showed that the nonconserved region in the $\mathrm{N}$-terminal extension domain of PMTV TGBp1 could be deleted without interference with intra- and intercellular TGBp1 trafficking mediated by TGBp2 and TGBp3. Presumably, the N-proximal terminus of TGBp1 has no major impact on the functional interactions with TGBp2 and TGBp3.

Collectively, our data consolidate the general model of cellto-cell movement mediated by hordei-like TGB (Morozov and Solovyev 2003). According to this model, TGBp1 forms a movement-competent complex with viral RNA, whereas TGBp2 and TGBp3 function as membrane anchors. TGBp2 and TGBp3 provide signals for the intracellular trafficking of the RNA-TGBp1 complex associated with a surface of putative membrane vesicles to plasmodesmata-enriched cell wall regions. Importantly, intracellular translocation of TGBp1 to the cell periphery is independent of the NTPase or helicase activities of TGBp1. These activities, however, are crucial during the next step when TGBp1, or a movement-competent RNP, enters plasmodesmata and moves from cell to cell.

\section{MATERIALS AND METHODS}

Construction of recombinant clones.

The constructs for transient expression of PSLV TGBp2, PSLV TGBp3, PVX TGBp2, PVX TGBp3, and nonfused GFP were described previously (Solovyev et al. 2000). For cloning, standard procedures were used (Sambrook et al. 1989).

To construct pRT-GFP-TGBp1, the PMTV TGBpl gene was amplified from the PMTV genomic RNA3 full-length cDNA clone (pPMTV-3) (Savenkov et al. 2003) using a pair of primers, p1-N-Mun-Bam and p1-C-Xba. The PCR product was digested with $B a m \mathrm{HI}$ and $\mathrm{XbaI}$, and ligated into similarly digested pRT-GFP-18K (Solovyev et al. 2000). pRT-GFP-TGBp1 was amplified with primers Mlu-P1 and R22 that anneal to the pRT100 sequence downstream from the multiple cloning site, digested with $M l u \mathrm{I}$ and $X b a \mathrm{I}$, and cloned into similarly digested pRT-GFP-TGBp1, to obtain pRT-GFP-TGBp1-Mlu1. To make pRT-GFP-TGBp1-GKT (Fig 4A), the TGBp1 was amplified using two pairs of primers, L20 (that anneals to the pRT100 sequence upstream of the multiple cloning site) and GKT-Xho$\mathrm{M}$ or GKT-Xho-P and R22. The PCR products were digested with EcoRI and XhoI or XhoI and $X b a I$, respectively, and cloned simultaneously into EcoRI- and XbaI-digested pRT-GFPTGBp1. To obtain the mutant pRT-GFP-TGBp1-delC, the TGBpl gene was amplified using oligonucleotides L20 and p1AX-M. The PCR product was digested with XhoI and $X b a \mathrm{I}$ and cloned into XhoI- and XbaI-cleaved pRT-GFP-TGBp1. pPMTV3 (Savenkov et al. 2003) was used as the template to amplify the PMTV TGBp2 and TGBp3 genes using either primers p2-NBam and p2-C-Xba (for the gene of TGBp2), or p3-N-Bam and p3-C-Xba (for the TGBp3 gene). PCR products were digested with $N c o I$ and $X b a I$ and cloned into NcoI- and XbaI-digested pRT-GFP-18K (Solovyev et al. 2000) to replace GFP-18K, giving rise to pRT-TGBp2 or pRT-TGBp3. The GFP gene from pRT-GFP-18K was excised by $N c o$ I digestion and cloned into NcoI-digested pRT-TGBp2 to obtain pRT-GFP-TGBp2. For the bicistronic construct pRT-TGBp2/TGBp3, the MunI and XbaI fragment was excised from pRT-TGBp3 and cloned into MunIand $X b a I$-digested pRT-TGBp2. To construct pRT-TGBp2BspM/TGBp3 (Fig. 1), pRT-TGBp2/TGBp3 was digested with $B s p \mathrm{MII}$ and the $3^{\prime}$-prime ends were filled in by the Klenow treatment prior to ligation. The BNYVV TGBp3 gene was amplified with the primer pair BNYVV-Xho-P and BNYVVBgl-M using a cloned BNYVV TGB (Rg1 isolate) (Kruse et al. 1994) as a template. The resulting PCR product was digested with XhoI and $B g l \mathrm{II}$, and cloned into XhoI- and BamHI-digested pRT100 (Töpfer et al. 1987) to obtain pRT-BNYVV-TGBp3. To construct pRT-PSLV-TGBp2/TGBp3, the Eco32I and AflII fragment containing TGBp2 was excised from p684 (Solovyev et al. 1999) and cloned into pRT-18K plasmid (Solovyev et al. 2000) digested with EcoRI and XbaI, in which the EcoRI 3' ends were filled in by the Klenow treatment. To obtain the mutant pRTTGBp2-GG.DG/TGBp3 (Fig. 4B), TGBp2/TGBp3-encoding sequence was amplified using the primers L20/GDGG-Xho-M and GDGG-Xho-P/R22. PCR products were digested with $E c o$ RI and $X h o I$ and $X h o I$ and $X b a I$, respectively, and cloned simultaneously into EcoRI- and $X b a I$-digested pRT100 (Töpfer et al. 1987). pRT-TGBp2/TGBp3 was amplified using the oligonucleotides L20/QDLN-Xho-M and QDLN-Xho-P/R22 or L20/nonCons-Xho-M and nonCons-Xho-P/R22, digested with $E c o$ RI and XhoI and XhoI and XbaI, and cloned simultaneously into EcoRI- and XbaI-digested pRT100 to obtain pRT-TGBp2/TGBp3-QDLN or pRT-TGBp2/TGBp3-nonCons (Fig. 4B). To obtain pRT-TGBp2-delCp2/TGBp3, pRTTGBp2/TGBp3 was amplified with primers L20/Mun-M and Mun-P-delCp2/R22, digested with XhoI and MunI or MunI and $X b a \mathrm{I}$, and simultaneously cloned into XhoI- and XbaI-digested pRT100 (Töpfer et al. 1987). pRT-TGBp2/TGBp3 amplification products obtained using primers L20/Mun-M-H or Eco-PCys/R22 were digested with XhoI and MunI or EcoRI and XbaI and simultaneously cloned into XhoI- and XbaI-digested pRT100 to give pRT-TGBp2/TGBp3-delCys. To obtain 
pPMTV-3-nonCons, a BspMII and AflII fragment was excised from pRT-TGBp2/TGBp3-nonCons and cloned into BspMIIand AflII-digested pPMTV-3 (Savenkov et al. 2003). Using similar restriction sites, the fragments encoding mutated TGBp2 or TGBp3 were excised from pRT-TGBp2/TGBp3-QDLN, pRT-TGBp2-delCp2/TGBp3, pRT-TGBp2/TGBp3-Cys, or pRTTGBp2-GD.GG/TGBp3 and cloned into BspMII- and AflIIdigested pPMTV-3 to give rise to pPMTV-3-QDLN, pPMTV3-delCp2, pPMTV-3-Cys, or pPMTV-3-GD.GG. A MluI and BspMII fragment was excised from pRT-GFP-TGBp1-GKT and cloned into similarly digested pPMTV-3 to give rise to pPMTV-3-GKT. To construct pPMTV-3-GFP-TGBp1, pRTGFP-TGBp1 was amplified using oligonucleotides LEFT/GKTXho-M, whereas pPMTV-3 was amplified using the pair M13 universe/RNA3-Nco-M. PCR products were digested with SacI and NcoI or NcoI and KpnI and simultaneously cloned into SacI- and KpnI-digested pPMTV-3 (Savenkov et al. 2003). The eYFP gene (Clontech, Palo Alto, CA, U.S.A.) was amplified with primers YFP-Eco-P/YFP-Xba-HDEL-M, and the obtained PCR product was digested with EcoRI and XbaI, and cloned into similarly digested pRT-m-GFP5-ER (Zamyatnin et al. 2002) to replace the GFP gene to give rise to pRT-YFP-ER.

\section{Plant material, transient expression, and fluorescent microscopy.}

Leaves of 5 to $7 \mathrm{~cm}$ in length were detached from 6- to 8week-old $N$. benthamiana plants for the particle bombardment assay which employed the PDS-1000 system (BioRad, Hercules, CA, U.S.A.) as described by Morozov and associates (1997). For co-bombardment of leaves with two or three different constructs, a mixture of plasmids was precipitated on the tungsten particle surface in equimolar ratio. A Zeiss CLSM 410 confocal imaging system at Uppsala Ganetics Center was used to study subcellular localization of GFP fusion proteins. GFP was excited using a $\mathrm{Kr} / \mathrm{Ar}$ laser $(488 \mathrm{~nm})$. GFP emission was detected using a bandpass filter for 510 to $525 \mathrm{~nm}$. For imaging of coexpressed YFP and GFP constructs, a Leica TCS SP2 CLSM imaging system was used. Excitation lines of an argon ion laser of $488 \mathrm{~nm}$ for GFP and $514 \mathrm{~nm}$ for YFP were used alternately. Accordingly, fluorescence of GFP and YFP was detected alternately using a "switching between lines" option of the confocal system in a 496- to 510-nm acquisition window for GFP and 560- to 615-nm window for YFP. In this way, any bleeding of fluorescence between channels was eliminated (Brandizzi et al. 2002). Projection of serial optical sections was performed using Carl Zeiss LSM software (version 3.98) (Jena, Germany) and Adobe Photoshop (version 6.0) (Seattle).

\section{Infection of plants and virus detection.}

Prior to transcription, pPMTV-3, pPMTV-3-nonCons, pPMTV-3-QDLN, pPMTV-3-delCp2, pPMTV-3-Cys, or pPMTV-3-GD.GG, pPMTV-3-GKT, and pPMTV-3-GFPTGBp1 were linearized with SpeI. Full-length cDNA clones for PMTV RNA1 and RNA2 were linearized with MluI. In vitro transcripts were generated as described previously (Savenkov et al. 2003). N. benthamiana plants were inoculated with the transcripts in GKP buffer (50 mM glycin, $30 \mathrm{mM} \mathrm{K}{ }_{2} \mathrm{PO}_{4}, \mathrm{pH}$ $9.2,1 \%$ bentonite, $1 \%$ celite). Inoculated plants were analyzed by enzyme-linked immunosorbent assay at 14 days postinoculation as described by Germundsson and associates (2002).

\section{ACKNOWLEDGMENTS}

Financial support from The Royal Swedish Academy of Sciences (KVA); the Forestry and Agricultural Research Council (SJFR, grants 30.0645/97 and 30.0453/00); the Swedish Research Council for Environment, Agricultural Sciences and Spatial Planning (FORMAS, grant 22.0/2003-0859); Carl Tryggers Stiftelse; INTAS (grant 01-2379);
Volkswagen-Stiftung, Federal Republic of Germany; Russian Foundation for Basic Research (RFBR); and Grant of the President of Russian Federation (MD-130.2003.04) is gratefully acknowledged. We thank P. Bozhkov for his critical reading of the manuscript.

\section{LITERATURE CITED}

Bleykasten, C., Gilmer, D., Guilley, H., Richards, K. E., and Jonard, G. 1996. Beet necrotic yellow vein virus $42 \mathrm{kDa}$ triple gene block protein binds nucleic acid in vitro. J. Gen. Virol. 77:889-897.

Brakke, M. K., Ball, E. M., and Langenberg, W. G. 1988. A non-capsid protein associated with unencapsidated virus RNA in barley infected with Barley stripe mosaic virus. J. Gen. Virol. 69:481-491.

Brandizzi, F., Frangne, N., Marc-Martin, S., Hawes, C., Neuhaus, J. M. and Paris, N. 2002. The destination for single-pass membrane proteins is influenced markedly by the length of the hydrophobic domain. Plant Cell 14:1077-1092.

Caruthers, J. M., and McKay, D. B. 2002. Helicase structure and mechanism. Curr. Opin. Struct. Biol. 12:123-133.

Chapman, S., Hills, G., Watts, J., and Baulcombe, D. 1992. Mutational analysis of the coat protein gene of Potato virus $X$ : effects on virion morphology and viral pathogenicity. Virology 191:223-230.

Cowan, G. H., Lioliopoulou, F., Ziegler, A., and Torrance, L. 2002. Subcellular localization, protein interactions, and RNA binding of Potato mop-top virus triple gene block proteins. Virology 298:106-115.

Donald, R. G., Lawrence, D. M., and Jackson, A. O. 1997. The Barley stripe mosaic virus 58-kilodalton beta (b) protein is a multifunctional RNA binding protein. J. Virol. 71:1538-1546.

Erhardt, M., Herzog, E., Lauber, E., Fritsch, C., Guilley, H., Jonard, G., Richards, K. E., and Bouzoubaa, S. 1999a. Transgenic plants expressing the TGB 1 protein of Peanut clump virus complement movement of TGB1-defective Peanut clump virus but not of TGB1-defective Beet necrotic yellow vein virus. Plant Cell Rep. 18:614-619.

Erhardt, M., Morant, M., Ritzenthaler, C., Stussi-Garaud, C., Guilley, H., Richards, K. E., Jonard, G., Bouzoubaa, S., and Gilmer, D. 2000. P42 movement protein of Beet necrotic yellow vein virus is targeted by the movement proteins P13 and P15 to punctate bodies associated with plasmodesmata. Mol. Plant-Microbe Interact. 13:520-528.

Erhardt, M., Stussi-Garaud, C., Guilley, H., Richards, K. E., Jonard, G., and Bouzoubaa, S. 1999b. The first triple gene block protein of Peanut clump virus localizes to the plasmodesmata during virus infection. Virology 264:220-229.

Escobar, N. M., Haupt, S., Thow, G., Boevink, P., Chapman, S., and Oparka, K. J. 2003. High-throughput viral expression of cDNA-green fluorescent protein fusions reveals novel subcellular addresses and identifies unique proteins that interact with plasmodesmata. Plant Cell 15:1507-1523.

Fedorkin, O. N., Solovyev, A. G., Yelina, N. E., Zamyatnin, A. A., Jr., Zinovkin, R. A., Mäkinen, K., Schiemann, J., and Morozov, S. Y. 2001. Cell-to-cell movement of Potato virus $X$ involves distinct functions of the coat protein. J. Gen. Virol. 82:449-458.

Forster, R. L., Beck, D. L., Guilford, P. J., Voot, D. M., Van Dolleweerd, C. J., and Andersen, M. T. 1992. The coat protein of white clover mosaic potexvirus has a role in facilitating cell-to-cell transport in plants. Virology 191:480-484.

Geourjon, C., Orelle, C., Steinfels, E., Blanchet, C., Deleage, G., Di Pietro, A., and Jault, J. M. 2001. A common mechanism for ATP hydrolysis in $\mathrm{ABC}$ transporter and helicase superfamilies. Trends Biochem. Sci. 26:539-544.

Germundsson, A., Sandgren, M., Barker, H., Savenkov, E. I., and Valkonen, J. P. T. 2002. Initial infection of roots and leaves reveals different resistance phenotypes associated with coat protein gene-mediated resistance to Potato mop-top virus. J. Gen. Virol. 83:1201-1209.

Gorshkova, E. N., Erokhina, T. N., Stroganova, T. A., Yelina, N. E., Zamyatnin, A. A., Jr., Kalinina, N. O., Schiemann, J., Solovyev, A. G., and Morozov, S. Y. 2003. Immunodetection and fluorescent microscopy of transgenically expressed hordeivirus TGBp3 movement protein reveals its association with ER elements in close proximity to plasmodesmata. J. Gen. Virol. 84:985-994.

Haseloff, J., Siemering, K. R., Prasher, D. C., and Hodge, S. 1997. Removal of a cryptic intron and subcellular localization of green fluorescent protein are required to mark transgenic Arabidopsis plants brightly. Proc. Natl. Acad. Sci. U.S.A. 94:2122-2127.

Kalinina, N. O., Fedorkin, O. N., Samuilova, O. V., Maiss, E., Korpela, T. Morozov, S. Y., and Atabekov, J. G. 1996. Expression and biochemical analyses of the recombinant Potato virus $X 25 \mathrm{~K}$ movement protein. FEBS (Fed. Eur. Biochem. Soc.) Lett. 397:75-78.

Kalinina, N. O., Rakitina, D. A., Solovyev, A. G., Schiemann, J., and Morozov, S. Y. 2002. RNA helicase activity of the plant virus movement proteins encoded by the first gene of the triple gene block. Virology 296:321-329. 
Kalinina, N. O., Rakitina, D. A., Yelina, N. E., Zamyatnin, A. A., Jr., Stroganova, T. A., Klinov, D. V., Prokhorov, V. V., Ustinova, S. V., Chernov, B. K., Schiemann, J., Solovyev, A. G., and Morozov, S. Y. 2001. RNA binding properties of the 63-kDa protein encoded by the triple gene block of Poa semilatent hordeivirus. J. Gen. Virol. 82:2569-2578.

Koenig, R., Beier. C., Commandeur, U., Luth, U., Kaufmann, A., and Luddecke, P. 1996. Beet soil-borne virus RNA 3-a further example of the heterogeneity of the gene content of furovirus genomes and of triple gene block-carrying RNAs. Virology 216:202-207.

Krishnamurthy, K., Heppler, M., Mitra, R., Blancaflor, E., Payton, M. Nelson, R. S., and Verchot-Lubicz, J. 2003. The Potato virus X TGBp3 protein associates with the ER network for virus cell-to-cell movement. Virology 309:135-151.

Krishnamurthy, K., Mitra, R., Payton, M. E., and Verchot-Lubicz, J. 2002. Cell-to-cell movement of the PVX $12 \mathrm{~K}, 8 \mathrm{~K}$, or coat proteins may depend on the host, leaf developmental stage, and the PVX $25 \mathrm{~K}$ protein. Virology 300:269-281.

Kruse, M., Koenig, R., Hoffmann, A., Kaufmann, A., Commandeur, U. Solovyev, A. G., Savenkov, E. I., and Burgermeister, W. 1994. Restriction fragment length polymorphism analysis of reverse transcriptionPCR products reveals the existence of two major strain groups of Beet necrotic yellow vein virus. J. Gen. Virol. 75:1835-1842.

Lawrence, D. M., and Jackson, A. O. 2001. Interactions of the TGB1 protein during cell-to-cell movement of Barley stripe mosaic virus. J. Virol. 75:8712-8723.

Lauber, E., Bleykasten-Grosshans, C., Erhardt, M., Bouzoubaa, S., Jonard, G., Richards, K. E., and Guilley, H. 1998. Cell-to-cell movement of Beet necrotic yellow vein virus: I. Heterologous complementation experiments provide evidence for specific interactions among the triple gene block proteins. Mol. Plant-Microbe Interact. 11:618-625.

Lough, T. J., Netzler, N. E., Emerson, S. J., Sutherland, P., Carr, F., Beck, D. L., Lucas, W. J., and Forster, R. L. 2000. Cell-to-cell movement of potexviruses: evidence for a ribonucleoprotein complex involving the coat protein and first triple gene block protein. Mol. Plant-Microbe Interact. 13:962-974.

Lough, T. J., Shash, K., Xoconostle-Cázares, B., Hofstra, K. R., Beck, D. L., Balmori, E., Forster, R. L. S., and Lucas, W. J. 1998. Molecular dissection of the mechanism by which potexvirus triple gene block proteins mediate cell-to-cell transport of infectious RNA. Mol. PlantMicrobe Interact. 11:801-814.

Lu, X., Yamamoto, S., Tanaka, M., Hibi, T., and Namba, S. 1998. The genome organization of the Broad bean necrosis virus (BBNV). Arch Virol. 143:1335-1348.

McGeachy, K. D., and Barker, H. 2000. Potato mop-top virus RNA can move long distance in the absence of coat protein: evidence from resistant, transgenic plants. Mol. Plant-Microbe Interact. 13:125-128.

Mitra, R., Krishnamurthy, K., Blancaflor, E., Payton, M., Nelson, R. S., and Verchot-Lubicz, J. 2003. The Potato virus $X$ TGBp2 protein association with the endoplasmic reticulum plays a role in but is not sufficient for viral cell-to-cell movement. Virology 312:35-48.

Morozov, S. Y., Dolja, V. V., and Atabekov, J. G. 1989. Probable reassortment of genomic elements among elongated RNA-containing plant viruses. J. Mol. Evol. 29:52-62.

Morozov, S. Y., Fedorkin, O. N., Jüttner, G., Schiemann, J., Baulcombe, D. C., and Atabekov, J. G. 1997. Complementation of a Potato virus X mutant mediated by bombardment of plant tissues with cloned viral movement protein genes J. Gen. Virol. 78:2077-2083.
Morozov, S. Y., and Solovyev, A. G. 2003. Triple gene block: modular design of a multifunctional machine for plant virus movement. J. Gen Virol. 84:1351-1366.

Morozov, S. Y., Solovyev, A. G., Kalinina, N. O., Fedorkin, O. N., Samuilova, O. V., Schiemann, J., and Atabekov, J. G. 1999. Evidence for two nonoverlapping functional domains in the Potato virus $X 25 \mathrm{~K}$ movement protein. Virology 260:55-63.

Oparka, K. J. 2004. Getting the message across: how do plant cells exchange macromolecular complexes? Trends Plant Sci. 9:33-41.

Oparka, K. J., and Roberts, A. G. 2001. Plasmodesmata. A not so openand-shut case. Plant Physiol. 125:123-126.

Rouleau, M., Smith, R. J., Bancroft, J. B., and Mackie, G. A. 1994. Purification, properties, and subcellular localization of Foxtail mosaic potexvirus 26-kDa protein. Virology 204:254-265.

Sambrook, J., Fritsch, E. F., and Maniatis, T. A. 1989. Molecular Cloning: A Laboratory Manual. Cold Spring Harbor Laboratory Press, Cold Spring Harbor, NY, U.S.A

Savenkov, E. I., Germundsson, A., Zamyatnin, A. A., Jr., Sandgren, M. and Valkonen, J. P. T. 2003. Potato mop-top virus: the coat proteinencoding RNA and the gene for cysteine-rich protein are dispensable for systemic virus movement in Nicotiana benthamiana. J. Gen. Virol. 84:1001-1005.

Scott, K. P., Kashiwazaki, S., Reavy, B., and Harrison B. D. 1994. The nucleotide sequence of Potato mop-top virus RNA 2: a novel type of genome organization for a furovirus. J. Gen. Virol. 75:3561-3568.

Solovyev, A. G., Savenkov, E. I., Agranovsky, A. A., and Morozov, S. Y. 1996. Comparisons of the genomic cis-elements and coding regions in RNA $\beta$ components of the hordeiviruses Barley stripe mosaic virus, Lychnis ringspot virus, and Poa semilatent virus. Virology 219:9-18.

Solovyev, A. G., Savenkov, E. I., Grdzelishvili, V. Z., Kalinina, N. O. Morozov, S. Y., Schiemann, J., and Atabekov, J. G. 1999. Movement of hordeivirus hybrids with exchanges in the triple gene block. Virology 253:278-287.

Solovyev, A. G., Stroganova, T. A., Zamyatnin A. A., Jr., Fedorkin, O. N., Schiemann, J., and Morozov, S. Y. 2000. Subcellular sorting of small membrane-associated triple gene block proteins: TGBp3-assisted targeting of TGBp2. Virology 269:113-127.

Tamai, A., and Meshi, T. 2001. Cell-to-cell movement of Potato virus X: the role of p12 and p8 encoded by the second and third open reading frames of the triple gene block. Mol. Plant-Microbe Interact. 14:1158-1167.

Töpfer, R., Matzeit, V., Gronenborn, B., Schell, J., and Steinbiss, H.-H. 1987. A set of plant expression vectors for transcriptional and translational fusions. Nucleic Acids Res. 15:5890.

Wung, C. H., Hsu, Y. H., Liou, D. Y., Huang, W. C., Lin, N. S., and Chang, B. Y. 1999. Identification of the RNA-binding sites of the triple gene block protein 1 of Bamboo mosaic potexvirus. J. Gen. Virol. 80:11191126.

Yang, Y., Ding, B., Baulcombe, D. C., and Verchot, J. 2000. Cell-to-cell movement of the $25 \mathrm{~K}$ protein of Potato virus $X$ is regulated by three other viral proteins. Mol. Plant-Microbe Interact. 13:599-605.

Zambryski, P. 2004. Cell-to-cell transport of proteins and fluorescent tracers via plasmodesmata during plant development. J. Cell Biol. 164:165-168.

Zamyatnin, A. A., Jr., Solovyev, A. G., Sablina, A. A., Agranovsky, A. A., Katul, L., Vetten, H. J., Schiemann, J., Hinkkanen, A. E., Lehto, K., and Morozov, S. Y. 2002. Dual-color imaging of membrane protein targeting directed by Poa semilatent virus movement protein TGBp3 in plant and mammalian cells. J. Gen. Virol. 83:651-662. 